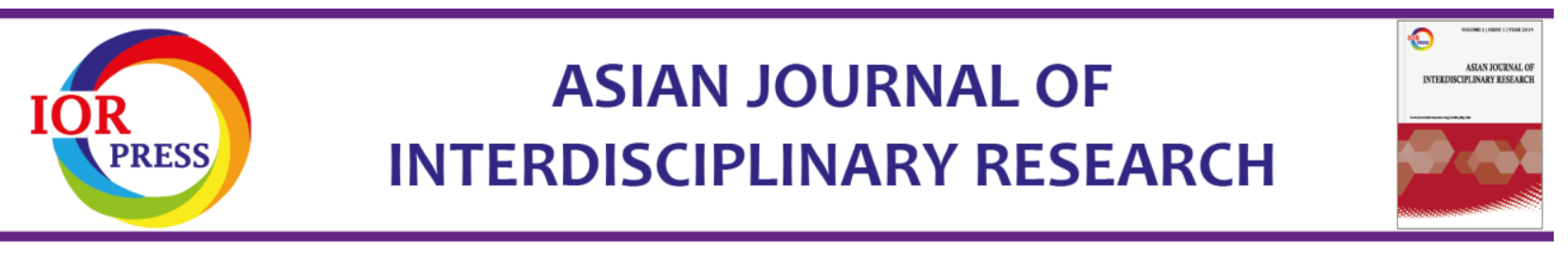

\title{
The Teaching Method of Science Subject in Primary Schools Based on Students' Competency Development: Results From a Field Study
}

\author{
Doan Thi Ngan a, Bui Van Hong a, b,* (iD \\ a Ho Chi Minh City University of Technology and Education, Ho Chi Minh City, Vietnam \\ b Thu Duc Education Enrichment School, Ho Chi Minh City, Vietnam \\ *Corresponding author email: hongbv@hcmute.edu.vn \\ DOI: https://doi.org/10.34256/ajir21112
}

Received: 23-02-2021

Revised: 24-03-2021

Accepted: 25-03-2021

Published: 26-03-2021

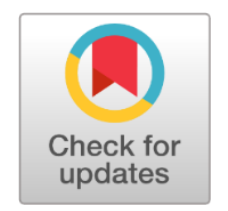

\begin{abstract}
Renovating the General Education Curriculum is one of the most important goals of the education renovation in Vietnam at the present. Particularly, the renovation of teaching methods has been receiving increasing attention during the past few years. This originates from the growing demands for social developments and the inadequacies of the current General Education curriculum. This article explores the current teaching methods used to teach the science subject with an orientation toward the development of students' competencies in primary schools in Ho Chi Minh City, Vietnam. This scientific and objective account will provide the foundation for improving teaching methods, enhancing the quality of science education in primary schools with an orientation toward students' competency development to meet the demands for the renovation of the General Education Curriculum at the primary level.
\end{abstract}

Keywords: Teaching methods, Science subject, Primary schools, Competency development, Field study

\section{Introduction}

In the age of educational renovation where the body of scientific knowledge is growing rapidly, more and more educators have abandoned the conventional way of delivering knowledge (Eurydice, 2006; Ministry, 2015). Instead, they teach learners the way to learn and help them form and develop the necessary competencies. As a result, renovating the current teaching methods has become a vital task. Responding to the new scenario in education, the General Education Curriculum (for primary level) issued under Circular 32/2018/TT-BGDDT by the Minister of Education and Training on December $26^{\text {th }}, 2018$ included many changes to the content and teaching methods. In particular, "all subjects and educational activities in schools must employ methods that promote students' autonomy. Teachers serve as facilitators who organize and provide guidance for students, creating a friendly learning environment. There should be learning problems to encourage students to participate in learning activities, recognize their own competencies and preferences, practice learning autonomy, enhancing their abilities and learned skills and knowledge for further development. Depending on the objectives and characteristics of the activities, students may work individually, in groups, or as a whole class. However, it is important to ensure that every student has the opportunity to complete learning tasks and gain experience 
on their own" (Ministry of Education and Training, 2018, p.28). It is clear that the focus of the renovation of the General Education Curriculum is on organizing experiential activities and developing students' competencies. Specifically, students should have the opportunities to be proactive in their learning in order to develop the competencies needed for social development. This calls for improvements in teaching methods to maximize students' autonomy, which, in turn, will contribute to competency development ( $T$. L. P. Nguyen, 2016). In this article, the authors conducted surveys on the current teaching methods for the science subject with an orientation toward developing students' competencies in primary school students in Ho Chi Minh City, Vietnam.

\section{Literature Review}

There is a long tradition of studies on competencies and competency development which has started to gain traction since the 70s of the $20^{\text {th }}$ century. Competencies and competency development are the focus of research as they are the goal of education, particularly, the educational outcomes of many countries' education curricula. Competencies and competency development allow students to be confident in learning, participate in personal and social activities effectively (The Ontario Public Service, 2016). In this form, education strives for the accurate measurements of learners' knowledge, skills, and attitudes after completing each learning program. Many researchers believe that competency-based education belongs to vocational training (Gonczi, Hager, \& Athanasou, 1993) and information technology (Mulder, Weigel, \& Collins, 2007). However, in reality, competency-based education is not reserved only for vocational training but also for general education and other fields.

Prominent works on competencies and competency development include those by
OECD (OECD, 2002), DeSeCo (DeSeCo, 2002), and Quebec's Ministry of Education (QuébecMinistere de L'Education, 2004). In Vietnam, there are also many impressive publications on this topic (Dang, 2012; H. B. Hoang, 2015; T. L. P. Nguyen, 2016). In general, those studies focus on several fundamental issues:

\section{Firstly, the definition of competencies and competency development}

There are many different ways to define competencies and competency development (OECD, 2002; Québec-Ministere de L'Education, 2004). Competencies are built on the foundation of knowledge, consolidated through values and structures such as abilities, developed by experiences, and concretized by humans' wills (DeSeCo, 2002).

\section{Secondly, the structure of competencies}

Prominent studies on the structure of competencies include the following:

- F. E. Weinert's structure model describes competencies by three major components - an individual's abilities, skills, and willingness to participate. This model does not take into account the component "knowledge." Moreover, it puts "abilities" as a component of competencies besides "skills," which is not reasonable (Weinert, 2001).

- Quebec's Secondary Education Curriculum states that competencies encompass three factors, namely, an individual's abilities, skills, and willingness to participate. Although it does not directly recognize knowledge, skills, and attitudes as the main components of competencies, those are considered the components of the resources needed to form competencies (Québec-Ministere de L'Education, 2004).

The most noticeable one is probably the perspective of Dang Thanh Hung and the research team from the Vietnam National 
Institute of Educational Sciences. They believe that competencies are different from the combination of knowledge, skills, and emotional behaviors. Competencies include knowledge, skills, and emotional behaviors (attitudes) expressed through the comprehension competency, doing competency, and feeling competency. When separated, those competencies serve no value because each of them is only a single facet of competencies as a whole. It is only when the teaching and learning practices help those competencies become highly integrated into an individual and they are tested by real-life experiences that a new competency can be formed wholely in that individual (L. Nguyen \& Nguyen, 2015).

Dang Thanh Hung summarized the competencies mentioned above into a map of competency structure (See Figure 1).

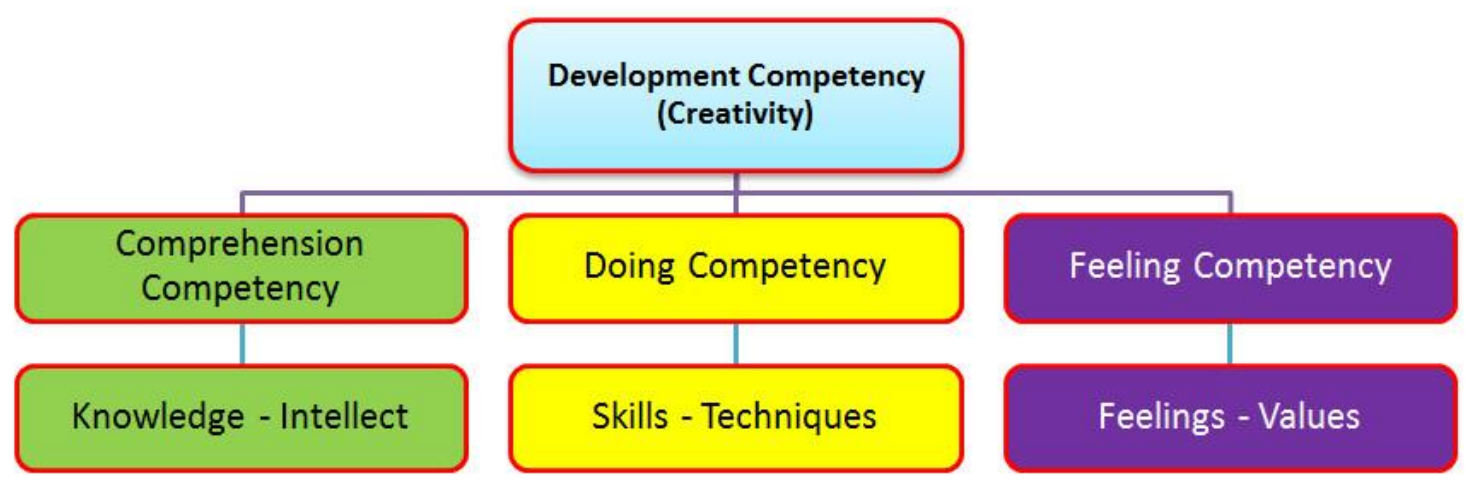

Figure 1. A map of competency structure (Dang, 2012)

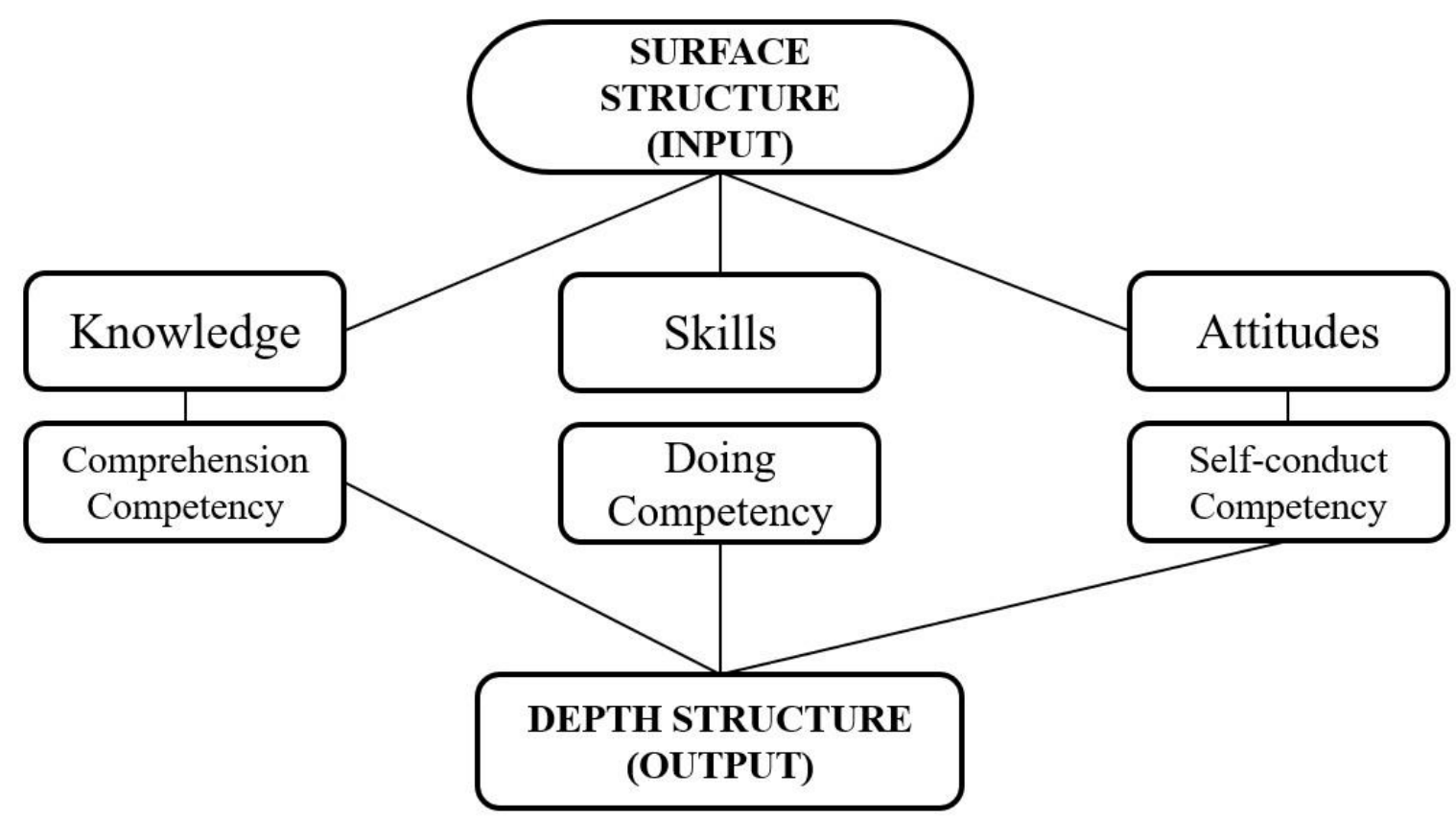

Figure 2. Competency structure (H. B. Hoang, 2015) 
Building on the perspective of Dang Thanh Hung and the research team from the Vietnam National Institute of Educational Sciences, Hoang Hoa Binh conceptualized the relationship among the resources making up competencies - knowledge, skills, and attitudes - and their representations in activities comprehension competency, doing competency, self-conduct competency. It is the relationship between the resources (input) and the results (output), or in other words, between the surface structure and the depth structure of competencies. This conceptualization has a significant meaning in the field of education. The structure of competencies and their component resources are presented in Figure 2.

According to this structure, in order to help students form and develop competencies, the teaching in schools must extend beyond simply equipping students with the knowledge, skills, and proper attitudes. It is important to turn the knowledge from textbooks into their own usable knowledge, make sure that they get to practice their skills, and apply what they have learned at school into their lives, forming proper living attitudes through each lesson. Students should have the chance to form and develop self-conduct behaviors that will become a part of their integrity. Therefore, the assessment will have to move away from testing knowledge, skills, and simple perceptions to evaluating students' know-how - the ability to apply and put knowledge into practice as well as their self-conduct behaviors in daily situations.

The material Integrating Teaching with Developing Students' Competencies argues that competencies are not a static structure. In fact, it is an open, constantly evolving structure with multiple components and levels, consisting of not only knowledge and skills but also beliefs, values, and social responsibilities. This is evident in its readiness to take action in specific conditions and changing situations (Do, 2015). The author Nguyen Xuan Thuc posits that the competency structure is dynamic, manifesting differently in each individual - never the same number or quality (X. T. Nguyen, 2014).

From a different viewpoint, Nguyen Lan Phuong does not see competencies as the integration of knowledge, skills, and attitudes. As she puts it, competencies include:

- Components: Areas of expertise making up competencies

- Elements: Sub-competencies or skills making up each component

- Behaviors: The constituents of each element (T. L. P. Nguyen, 2015)

As the authors understand it, analyzing competencies into components, elements, and behaviors is approaching the competency structure from its parts. This method of analysis may go both horizontally and vertically.

- First, every general or specific competency can be analyzed into competency components.

- Then, each component can be analyzed into more specific parts until it is possible to define their external behaviors.

Those competency parts (and behaviors) may be on the same level, complementing each other.

Combining these two approaches to analyzing the competency structure, the assessment of education results may be based on a matrix of development indicators of competency components and indicators of the comprehension competency, doing competency, and self-conduct competency. 
Thirdly, research on the content and assessment of competencies

The book Approaching competencies and assessment of learners' competencies (edited by Nguyen Thi Lan Phuong) was published in 2016 with four main parts and 13 chapters presenting a total of 464 pages of research. The content covers three fundamental domains education, teaching, and assessment with an orientation toward approaching competencies. In the third part, two chapters (chapters 6 and 7) were devoted to discussing the relevant concepts and methods to assess learners' competencies (T. L. P. Nguyen, 2016).

In addition, the article $A$ framework for designing courses: Integrating teaching, learning, and assessment based on a competency development model by Nguyen Thi Lan Phuong published in the Journal of Educational Sciences (Issue No. 129, June 2016) has proposed a framework to help with designing curricula that integrates teaching and competency assessment based on a competency development model (T. L. P. Nguyen, 2016).
Fourthly, research on teaching with an orientation toward competency development

Competency-based education became popular during the 1970s in the United States. With this form of education, the goal is to aim for an accurate assessment of students' knowledge, skills, and attitudes after each course. Many researchers believe that competency-based education should be for vocational training (Gonczi, Hager, \& Athanasou, 1993) and information technology (Mulder, Weigel, \& Collins, 2007). However, a closer look at reality reveals that competencybased education is not only for vocational training but it also works for other domains.

Miller (1990) proposed a pyramid model presenting four levels of education with an orientation toward competency development. This model serves as the tool to develop assessment methods and techniques as well as to determine learning outcomes. According to this model, at low levels, learners gain knowledge and skills while at higher levels, they can perform and take action with their competencies (As cited in T. T. Hoang, 2013)

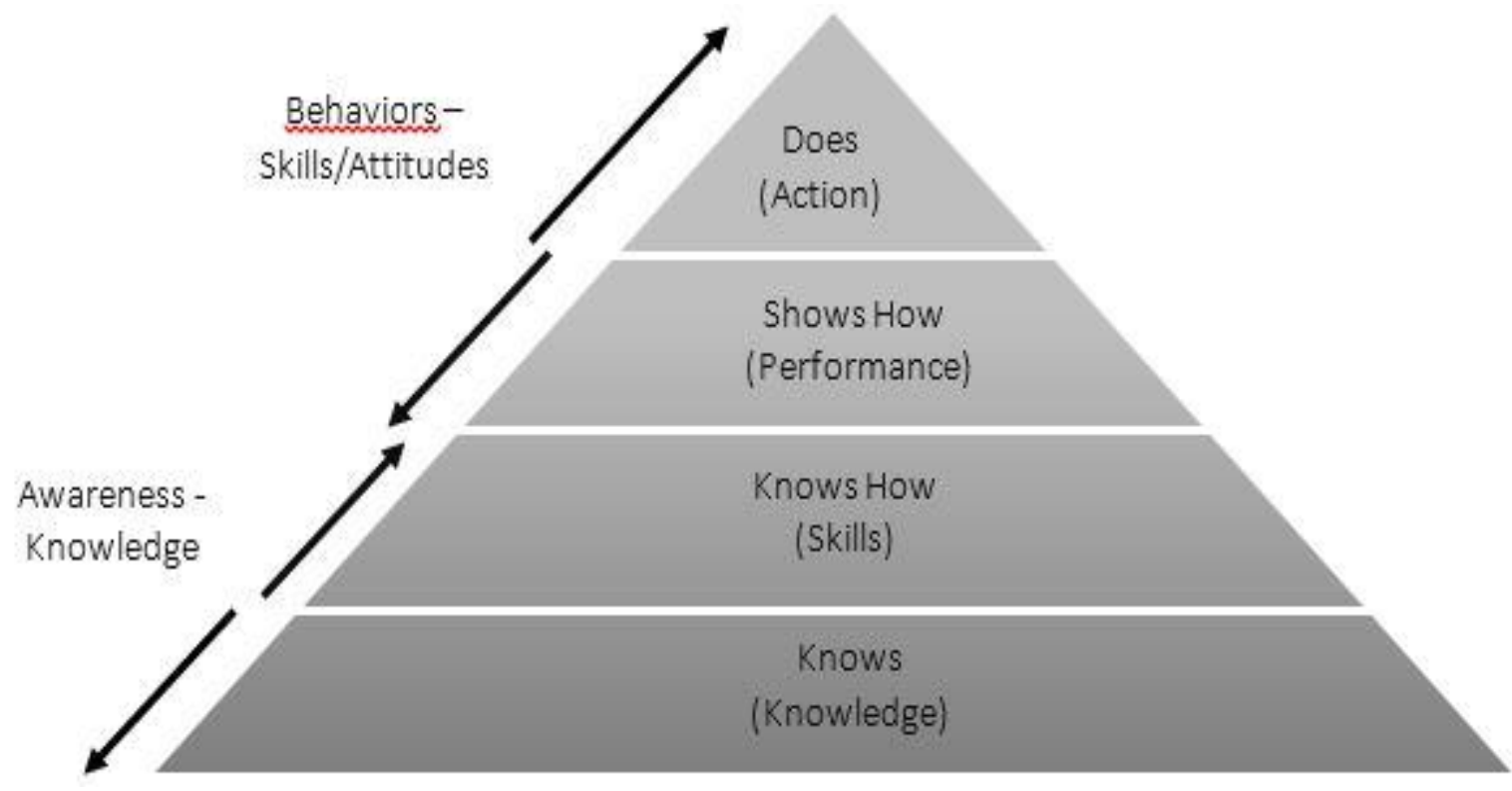

Figure 3. A competency development model (T. T. Hoang, 2013, p.82) 
According to the model illustrated in Figure 3, the development of learners' competencies are gone from a low level (awareness - understanding) to a higher level that is practice (experiment, presentation, practice, real-life actions, among others).

Vygotsky stressed that teaching must precede development and criticized teaching that follows development. From his perspective, on the one hand, teaching is organizing for students' development, leading them into their zone of proximal development and forming the next zone of proximal development. On the other hand, teaching practices should also respect and make use of students' underlying knowledge, providing level-appropriate learning to help students develop competencies. It is important to avoid the two extremes - stating what students already know and stating what they cannot possibly know (L. Nguyen \& Nguyen, 2016). The model demonstrates the difference between education curricula with conventional learning outcomes and competency-based education curricula. In Vietnam, the issue of competencies and education with an orientation toward competency development has also been receiving attention from many scientists, psychologists, and educators (Dang, 2012; H. B. Hoang, 2015; L. Nguyen \& Nguyen, 2016; T. L. P. Nguyen, 2015, 2016; Quach, 2019).

In the context of teaching science in primary schools, to develop students' competencies, teachers should renovate their teaching practices by being creative with teaching methods. Teaching should move away from passive lectures to an open process where students can investigate and discover on their own. The emphasis should be on practice and application in real-life situations, encouraging students to expand their knowledge through various sources of information (such as families, friends, and communities). In particular, it is important to incorporate a variety of teaching methods in a way that can develop students' proactivity, autonomy, and creativity. More specifically, teachers should choose teaching methods that not only allow students to be active in gaining knowledge but also contribute to their competencies, integrating intellectual activities with application and practice. The goal is to encourage students to form know knowledge naturally from their personal experiences. Teaching methods that should be used more in a flexible way include raising and solving problems, modeling, and practice-based teaching.

At the end of the 19th century, the British chemist Henry Edward Armstrong (1948-1937) introduced the heuristic method of teaching centered around the notion of investigation and discovery. Sixty years later, his method is known as learning through investigating, which is closely connected with the concept of discovery learning. These days, it has been widely implemented in the European Union and is known as the "Inquiry-Based Science Education" (Koutsoukos, Fragoulis, \& Valkanos, 2015).

Gagné (America) proposed a teaching model consisting of observations, question raising, discussions, practice, and experiments among which observations are most frequently conducted by teachers (Chapter 6, page 43). Besides, other studies recommend that teachers should employ constructive and experiential learning frequently (Jenkins, 2013). Outdoors activities should be organized to discover natural, scientific, and social phenomena with field investigation being the focus of scientific activities (The Government of Ireland, 1999). Use a combination of methods such as group work, individual work, and discovery learning to give students the opportunities to experience for themselves (The Government of Ireland, 1999). Sitting at their desk listening to lectures is not an interesting experience for learners - students should be able to work things out, practice, observe, cooperate with each other and share 
their ideas (Walma van der Molen, AalderenSmeets, \& Asma, 2010). Science should be considered as a verb, meaning students should be able to think and act as they learn through practice (Settlage \& Southerland, 2007). The most commonly used teaching methods include observation, investigation, experience, experiment, debate, role-playing, task-based learning, practice, encouraging students to raise questions and speak up, and using the Internet, among others. Parents' involvement in their children's learning process as they join scientific experiential activities with their children at night also contributes to enhancing their children's learning quality (Peacock, 2006).

According to the competency development trend in primary education, the teaching process must provide students with opportunities to experience and construct knowledge by themselves. As required by the General Education Curriculum (primary level) issued under Circular No. 32/2018/TT-BGDDT by the Minister of Education and Training on December $26^{\text {th }}, 2018$, it is essential to form and develop fundamental competencies such as autonomy competency, communication and cooperation competency, problem-solving and creative competency (Vietnam's Ministry of Education and Training, 2018). Competency development for primary school students is the major theme of the curriculum and its content. The guiding principles of the General Education Curriculum clearly state that "The curriculum ensures the development of students' characteristics and competencies through educational content, including basic knowledge and skills that are practical and up-to-date. It maintains the balance of integrity, intellect, physique, and beauty. The focus is on practice and application of learned knowledge and skills to solve problems in learning and real life. In lower grades, the curriculum is highly integrated and more evenly distributed in higher grades. The learning outcomes are achieved through teaching methods and organizations that promote students' autonomy and potentials as well as assessment tools that are appropriate for the learning outcomes and methodologies" (Vietnam's Ministry of Education and Training, 2018, p.5).

In primary education, competency development means to help students form and develop necessary competencies, including three general competencies and seven specific competencies as required in Vietnam's 2018 General Education Curriculum (Vietnam's Ministry of Education and Training, 2018, p.7). Competency development at the primary level requires teachers to determine the learning outcomes and necessary competencies to develop. The teachers need to design and organize classroom activities that can promote students' proactivity and autonomy. In addition, they should also have confidence and provide their students with encouragement to motivate them in their learning. Last but not least, assessment and testing must be fair, objective, and focus on formative assessment.

\section{Research Methodology}

This article employs a conceptual research approach to analyze and synthesize international and local scientific studies, articles, and other publications related to the teaching methods used in primary schools and students' competency development. In addition, to survey the current teaching practices, the authors conducted direct interviews to collect extensive data from school administrators, teachers, and students for analysis, discussion, and evaluation of results. Pedagogical observations were carried out in teachers' lessons and students' learning activities. Besides, the authors also conducted indirect interviews in the form of questionnaires. Data collected from the field survey played an essential role in the analysis and evaluation of the current situation of science teaching methods in Ho Chi Minh City, Vietnam. 
Using the random sampling method, the participants were chosen from the three target groups in 27 primary schools in 18/24 districts, including:

- 45 Principals and Vice Principals (Administrators)

- 354 teachers in charge of grades four and five

- 1880 students in grades four and five

Before delivering the questionnaires, the researchers contacted the Principal of the school via email to inform the purpose and content of the questionnaires, interviews, and classroom observations. After getting the Principal's approval, the researchers conducted the survey as planned.

The questionnaire includes both openended and closed-ended questions, using a three-point Likert scale for measurements.

* Statistical analysis: For the threepoint Likert scale:

The scores were assigned for each point as follows:

The first point: 1 score; The second point: 2 scores; The third point: 3 scores

After the questionnaires were collected, the data were analyzed using Excel and SPSS 20.0 (Statistical Package For The Social Sciences). The statistical analysis was as follows:

\begin{tabular}{|l|l|}
\hline Descriptive statistics & Abbreviation \\
\hline Mean & $\mathrm{M}$ \\
\hline Rank & T.h \\
\hline
\end{tabular}

*The meaning of each mean score in the interval scale

Range $=($ Maximum - Minimum $) / \mathrm{n}=(3-1) / 3$ $=0.67$

\begin{tabular}{|l|l|}
\hline Mean Score & Frequency \\
\hline $1,00-1,67$ & Never \\
\hline $1,68-2,35$ & Sometimes \\
\hline $2,36-3,00$ & Often \\
\hline
\end{tabular}

\section{Conceptual Framework}

Students form and develop competencies while learning the science subject in primary schools

Competencies are the integration of knowledge, skills, and psychological attributes such as motivation, will, and feelings to carry out an action or solve a problem in order to achieve favorable outcomes in a particular context.

The General Education Curriculum for the science subject under Circular No. 32/2018/TT-BGDDT issued by the Minister of Education and Training on December 26 2018 describes the competencies required by the science subject as follows (See Figure 4):

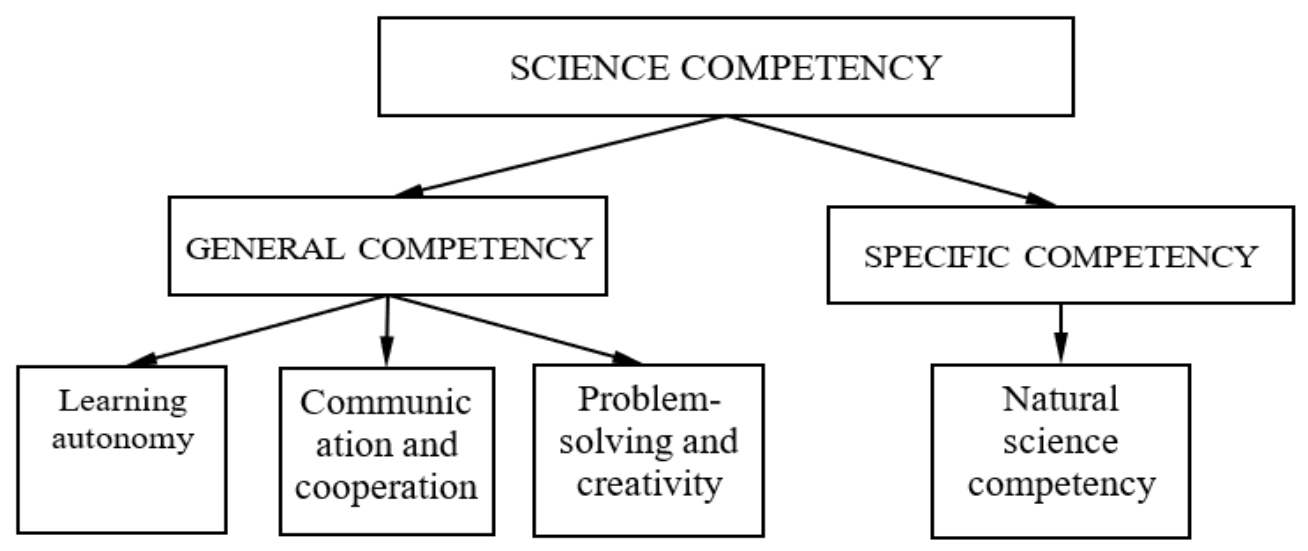

Figure 4. Primary school students' competency structure as required by the science subject (Vietnam's Ministry of Education and Training, 2018b, p.4-6) 


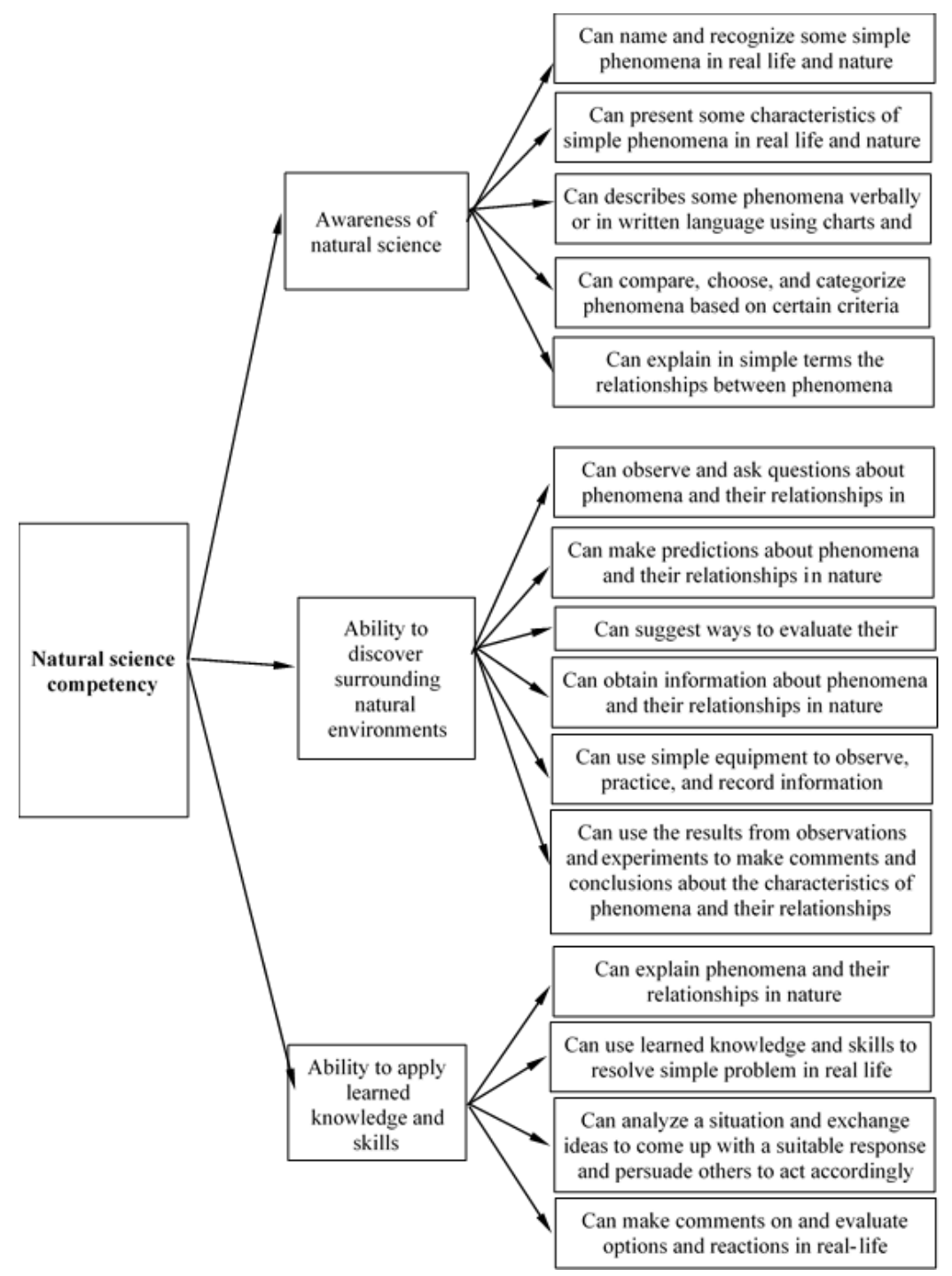

Figure 5. Components of the specific science competency (natural science competency) of primary school students (Vietnam's Ministry of Education and Training, 2018b, p.4-6)

Specific competency refers to natural science competency, including awareness of natural science, the ability to discover surrounding environments, and make use of learned knowledge and skills. The indicators of each competency component stated in the overall science curriculum are as follows (See Figure 5):

\section{Teaching methods to develop students' competencies through the science subject in primary schools}

Based on the competency components to be formed and developed, the teaching practices of the science subject in primary schools should combine the general group of teaching methods, the social science group of teaching methods, and the requirements for students' competency development. The authors have identified 14 major teaching methods for the science subject (See Figure 6).

- The group of teaching methods using verbal and written language includes Q\&A, discussion, instruction, storytelling, debate, and presentation.

- The group of visual teaching methods includes observations and visual aids.

- The group of practice-based teaching methods includes practice, brainstorm, 
experiment, investigation-discovery, role-playing, and problem raising and solving.

The learning process starts with the teacher giving students opportunities to experience and demonstrate their experiences in learning tasks or real-life situations. Students become stimulated as they observe and resolve problems, see pictures, touch and smell objects. After that, they participate in observation activities and reflect on their personal experiences to figure out the gap in their knowledge. Then, students can seek help from the teacher and their friends to build up new concepts and apply them to solve the problem. The teacher often uses visual teaching methods to help students muster their prior experiences to brainstorm, investigate, gather information, make predictions, and discover the problem. As a result, students gain new experiences (new knowledge) about phenomena and their surrounding environments, developing the competency to discover surrounding environments, communicate and cooperate with each other (Feeling Competency).
In the next stage, thanks to the teaching methods using verbal and written language such as Q\&A, discussion, instruction, and debate, students think and connect their experiences to new knowledge in every lesson. From there, they conceptualize their experiences, forming a firm grasp on scientific knowledge. The competencies to be aware of natural science and to be autonomous in their learning (Comprehension competency) are formed, consolidated, and developed.

Finally, to help students apply and practice the learned knowledge and skills (Doing competency) in real life, the teacher may use the practice-based group of teaching methods (practice, investigation, discovery, among others) to support the development of the competencies to solve problems, be creative, and apply learned knowledge and skills.

The development and integration of the general and specific competencies through the combination of three teaching method groups discussed above may result in students' development of science competencies, meeting the demands for competency development and the learning outcomes of the subject.

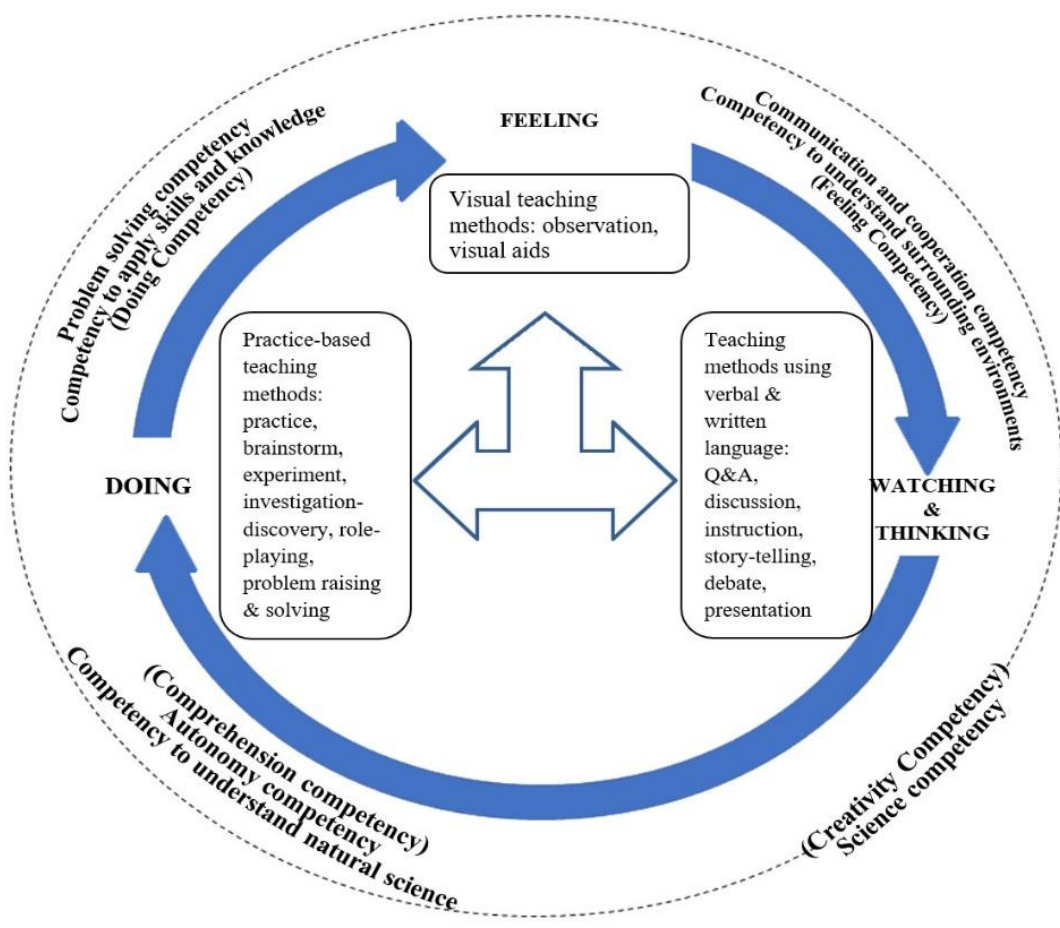

Figure 6. Teaching methods for the science subject with an orientation toward students' competency development 


\section{Results and Discussion}

\section{Results}

Based on the questionnaires delivered to 354 teachers and 45 administrators, observations, and interviews, the results are demonstrated as follows (see Table 1):

The results of the teacher survey show that in order to deliver science lessons, teachers often used 6 teaching methods, including Q\&A, observation, visual aids, instruction, discussion, and practice $(M \geq 2.65)$. The remaining eight teaching methods (problem raising and solving, brain-storming, story-telling, presentation, investigationdiscovery, debate, experiment, and role-play) were used occasionally (1.96 $\leq \mathrm{M} \leq 2.33)$.

Table 1. Results of the teacher survey on the frequency of teaching methods used

\begin{tabular}{|c|c|c|c|c|c|c|c|c|c|}
\hline \multirow[b]{2}{*}{$\begin{array}{l}\text { No } \\
\text {. }\end{array}$} & \multirow[b]{2}{*}{ Methods } & \multicolumn{2}{|l|}{ Never } & \multicolumn{2}{|c|}{ Sometimes } & \multicolumn{2}{|l|}{ Often } & \multirow[b]{2}{*}{$\mathbf{M}$} & \multirow[b]{2}{*}{$\begin{array}{l}\text { T. } \\
\text { h }\end{array}$} \\
\hline & & $\begin{array}{l}\text { Frequenc } \\
\mathrm{y}\end{array}$ & $\begin{array}{l}\text { Percentag } \\
\text { e }\end{array}$ & $\begin{array}{l}\text { Frequenc } \\
\mathrm{y}\end{array}$ & $\begin{array}{l}\text { Percentag } \\
\text { e }\end{array}$ & $\begin{array}{l}\text { Frequenc } \\
\mathrm{y}\end{array}$ & $\begin{array}{l}\text { Percentag } \\
\text { e }\end{array}$ & & \\
\hline 1 & Q\&A & / & / & 11 & 3.1 & 343 & 96.9 & $\begin{array}{l}2.9 \\
7\end{array}$ & 1 \\
\hline 2 & Observation & / & / & 28 & 2.9 & 326 & 92.1 & $\begin{array}{l}2.9 \\
2\end{array}$ & 2 \\
\hline 3 & Visual aids & / & / & 36 & 10.2 & 318 & 89.8 & $\begin{array}{l}2.9 \\
0\end{array}$ & 3 \\
\hline 4 & Instruction & 1 & 0.3 & 46 & 12.9 & 307 & 86.7 & $\begin{array}{l}2.8 \\
6\end{array}$ & 4 \\
\hline 5 & Discussion & / & / & 94 & 26.6 & 260 & 73.4 & $\begin{array}{l}2.7 \\
3\end{array}$ & 5 \\
\hline 6 & Practice & 1 & 0.3 & 122 & 34.5 & 231 & 65.2 & $\begin{array}{l}2.6 \\
5\end{array}$ & 6 \\
\hline 7 & $\begin{array}{l}\text { Problem } \\
\text { raising and } \\
\text { solving }\end{array}$ & 17 & 4.8 & 203 & 57.3 & 134 & 37.9 & $\begin{array}{l}2.3 \\
3\end{array}$ & 7 \\
\hline 8 & Brain storm & 22 & 6.2 & 195 & 55.1 & 137 & 38.7 & $\begin{array}{l}2.3 \\
2\end{array}$ & 8 \\
\hline 9 & Story-telling & 19 & 5.4 & 206 & 58.2 & 129 & 36.4 & $\begin{array}{l}2.3 \\
1\end{array}$ & 9 \\
\hline 10 & $\begin{array}{l}\text { Presentatio } \\
\mathrm{n}\end{array}$ & 24 & 6.8 & 211 & 59.6 & 119 & 33.6 & $\begin{array}{l}2.2 \\
7\end{array}$ & 10 \\
\hline 11 & $\begin{array}{l}\text { Investigate - } \\
\text { Discover }\end{array}$ & 29 & 8.2 & 229 & 64.7 & 96 & 27.1 & $\begin{array}{l}2.1 \\
9\end{array}$ & 11 \\
\hline 12 & Debate & 27 & 7.6 & 232 & 65.5 & 95 & 26.9 & $\begin{array}{l}2.1 \\
9\end{array}$ & 12 \\
\hline 13 & Experiment & 3 & 0.8 & 286 & 80.8 & 65 & 18.4 & $\begin{array}{l}2.1 \\
8\end{array}$ & 13 \\
\hline 14 & Role-play & 78 & 22.1 & 213 & 60.1 & 63 & 17.8 & $\begin{array}{l}1.9 \\
6\end{array}$ & 14 \\
\hline
\end{tabular}


Table 2. Results of the administrator survey on the frequency of teaching methods used by most teachers

\begin{tabular}{|l|l|l|l|l|l|l|l|l|l|}
\hline \multirow{2}{*}{ No. } & \multirow{2}{*}{ Methods } & Never & Frequency & Percentage & Frequency & Percentage & Frequency & Percentage & \multirow{2}{*}{ M } \\
\cline { 2 - 8 } & Q\&A & $/$ & $/$ & 3 & 6.7 & 42 & 93.3 & 2.93 & 3 \\
\hline 2 & Observation & $/$ & $/$ & 3 & 6.7 & 42 & 93.3 & 2.93 & 4 \\
\hline 3 & Visual aids & $/$ & $/$ & 2 & 4.4 & 43 & 95.6 & 2.96 & 2 \\
\hline 4 & Instruction & $/$ & $/$ & 7 & 15.6 & 38 & 84.4 & 2.84 & 5 \\
\hline 5 & Discussion & $/$ & $/$ & 1 & 2.2 & 44 & 97.8 & 2.98 & 1 \\
\hline 6 & Practice & $/$ & $/$ & 19 & 42.2 & 26 & 57.8 & 2.58 & 6 \\
\hline 7 & $\begin{array}{l}\text { Problem } \\
\text { raising and } \\
\text { solving }\end{array}$ & $/$ & $/$ & 30 & 66.7 & 15 & 33.3 & 2.33 & 9 \\
\hline 8 & Brainstorm & $/$ & $/$ & 30 & 66.7 & 15 & 33.3 & 2.33 & 10 \\
\hline 9 & Story-telling & $/$ & $/$ & 28 & 62.2 & 17 & 37.8 & 2.38 & 7 \\
\hline 10 & Presentation & $/$ & $/$ & 31 & 68.9 & 14 & 31.1 & 2.31 & 11 \\
\hline 11 & $\begin{array}{l}\text { Investigate } \\
\text { Discover }\end{array}$ & 1 & 2.2 & 39 & 86.7 & 5 & 11.1 & 2.09 & 14 \\
\hline 12 & Debate & 1 & 2.2 & 30 & 66.7 & 14 & 31.1 & 2.29 & 12 \\
\hline 13 & Experiment & $/$ & $/$ & 35 & 77.8 & 10 & 22.2 & 2.22 & 13 \\
\hline 14 & Role-play & $/$ & $/$ & 29 & 64.4 & 16 & 35.6 & 2.36 & 8 \\
\hline
\end{tabular}

The results of the administrator survey on the common teaching methods used by most teachers were as follows (see Table 2):

According to the administrators, two methods considered commonly used by teachers (more than recorded by the teacher survey) were story-telling and role-play. The six remaining methods were considered as sometimes used by teachers. The administrators based this evaluation on their unscheduled classroom observations. It seems that the results from the teacher survey and the administrator survey were quite similar.

Based on our classroom observations of 47 periods and direct interviews with students, the authors believe that when there were classroom observations, the teachers were more invested in teaching. Specifically, they put more effort into planning the lessons, organizing learning activities, designing games, and preparing teaching equipment. This is not a common practice for the average learning period (without the presence of observers).

The results of the student survey (involving 1,880 students) on the learning activities commonly used by teachers when teaching the science subject show that the learning activities commonly used by teachers were letting students learn by "Anwer questions raised by teacher or questions in textbooks" ( $\mathrm{M}=2.83$ ) and "Listen to teacher's instruction and memorize the lesson conclusion" ( $M=2.81)$. This means the teachers mostly used the conventional teaching method where they would lecture and their students would listen passively. The focus was mainly on the lesson content and students' competency development did not receive much attention. In addition, experiments were not used $(\mathrm{M}=1.40)$ (see Table 3): 
Table 3. Results of the student survey on student participation in science learning activities

\begin{tabular}{|c|c|c|c|c|c|c|c|c|c|}
\hline \multirow{2}{*}{ No. } & \multirow[b]{2}{*}{ Activities } & \multicolumn{2}{|l|}{ Never } & \multicolumn{2}{|c|}{ Sometimes } & \multicolumn{2}{|l|}{ Often } & \multirow[b]{2}{*}{$\mathbf{M}$} & \multirow[b]{2}{*}{ T.h } \\
\hline & & Frequency & Percentage & Frequency & Percentage & Frequency & Percentage & & \\
\hline 1 & $\begin{array}{ll}\text { Anwer } & \\
\text { questions } & \\
\text { raised } & \text { by } \\
\text { teacher } & \text { or } \\
\text { questions } & \text { in } \\
\text { textbooks } & \end{array}$ & 12 & 0.6 & 288 & 15.3 & 1580 & 84.1 & 2.83 & 1 \\
\hline 2 & $\begin{array}{l}\text { Listen to } \\
\text { teacher's } \\
\text { instruction } \\
\text { and memorize } \\
\text { the lesson } \\
\text { conclusion }\end{array}$ & 11 & 0.6 & 332 & 17.7 & 1537 & 81.8 & 2.81 & 2 \\
\hline 3 & $\begin{array}{lr}\text { Work } & \text { in } \\
\text { groups, } & \\
\text { discuss } & \text { to } \\
\text { learn } & \text { more } \\
\text { about } & \text { the } \\
\text { lesson } & \end{array}$ & 123 & 6.5 & 1138 & 60.6 & 619 & 32.9 & 2.26 & 3 \\
\hline 4 & $\begin{array}{l}\text { Observe } \\
\text { photos or } \\
\text { realia }\end{array}$ & 94 & 5.00 & 1208 & 64.3 & 578 & 30.7 & 2.26 & 4 \\
\hline 5 & $\begin{array}{lr}\text { Read books, } \\
\text { discuss } \\
\text { friends }\end{array}$ & 105 & 5.6 & 1318 & 70.1 & 457 & 24.3 & 2.19 & 5 \\
\hline 6 & $\begin{array}{l}\text { Play learning } \\
\text { games, answer } \\
\text { riddles, etc. }\end{array}$ & 94 & 5.00 & 1396 & 74.3 & 390 & 20.7 & 2.16 & 6 \\
\hline 7 & $\begin{array}{l}\text { Read the } \\
\text { textbook, then } \\
\text { memorize the } \\
\text { lesson } \\
\text { conclusion }\end{array}$ & 301 & 16.1 & 1114 & 59.2 & 465 & 24.7 & 2.09 & 7 \\
\hline 8 & $\begin{array}{l}\text { Debate, } \\
\text { present the } \\
\text { lesson content }\end{array}$ & 264 & 14.1 & 1322 & 70.3 & 294 & 15.6 & 2.02 & 8 \\
\hline 9 & $\begin{array}{l}\text { Investigate, } \\
\text { role-play to } \\
\text { discover the } \\
\text { lesson content }\end{array}$ & 396 & 21.1 & 1359 & 72.3 & 125 & 6.6 & 1.86 & 9 \\
\hline 10 & $\begin{array}{l}\text { Practice and } \\
\text { experiment }\end{array}$ & 1169 & 62.2 & 669 & 35.6 & 42 & 2.2 & 1.40 & 10 \\
\hline
\end{tabular}


Apparently, there are inconsistencies in the results from surveying administrators, teachers, and students about the current teaching methods. In order to account for such inadequacies, the authors carried out direct interviews with students. The findings reveal that the common teaching practices involved teachers letting students read the textbooks by themselves first. Then, the teachers would provide instructions and the students would memorize the lesson summaries. The most commonly used teaching method was instruction (which belongs to the group of teaching methods using verbal and written language). It seems that the teachers mostly used conventional teaching methods that focused heavily on the lesson content.

To gain an objective and multifaceted perspective, the authors also investigated the reasons why most teachers only used one teaching method (which was instruction, according to the student survey results) by delivering questionnaires and interviewing the administrators and teachers. The findings are as follows:

The majority of teachers reported a lack of teaching facilities and equipment, large class sizes, having students with different levels of competencies in the same class, and limited physical spaces (especially in the urban areas). Consequently, they often found it difficult to use other teaching methods such as experiments, investigation-discovery, or visual aids. Similarly, the large class sizes (of over 40 students per class) made it impossible to have $100 \%$ of the students participating in experiments and practice activities.

Classroom safety was also one of the major concerns raised by the teachers. When the teachers organized physical activities, experiments, or learning games, the students often damaged the teaching equipment, tools, or models. Besides, not all students had the proper learning awareness and attitude. While some students were interested in learning and participated actively in such activities, many others were usually distracted, exhibiting disruptive behaviors, and were not careful when handling the equipment. There were also students who were shy and afraid, always sitting back from activities.

\section{Discussion}

The surveys conducted to investigate the current teaching practices of teachers in charge of the science subject yielded both consistencies and inconsistencies in results. The results were consistent in the way administrators, teachers, and students agreed that the most commonly used teaching methods were Q\&A and instruction (belonging to the group of teaching methods using verbal and written language). In contrast, the results were inconsistent when it came to the number and the specific teaching methods that teachers often used and never used. According to the teachers, there were four more commonly used methods (in comparison with the findings from students), including observations, visual aids, discussion, and practice. Interestingly, when compared to the administrator survey, there were two other methods regarded as commonly used - story-telling and roleplaying. In total, there were six methods that the students did not consider as commonly used by their teachers (observations, visual aids, discussion, practice, story-telling, and role-playing).

There are several reasons for the inconsistent results mentioned above. Based on the authors' 47 classroom observations and interviews with administrators, teachers, and students, the major reason seems to be the effect of the classroom observations. When there were classroom observations, the teachers were more invested and used more teaching methods to help students learn and receive knowledge. Consequently, learning activities were more diverse, the students were more interested and participated in the lessons 
to build up more knowledge for themselves. In contrast, when there were no classroom observations, most teachers often used two methods, namely Q\&A and instruction to save time and ensure that they could deliver the basic knowledge to students. The experiment method was not used. Teachers' overuse of the two conventional teaching methods was the primary cause of students' lack of interest in the science subject. These practices failed to develop students' competencies effectively. The teaching leaned heavily toward the lesson content without paying attention to competency development. The findings from this field study explain the need for renovating the General Education Curriculum at the primary level. It also calls for improvements in the use of active teaching methods not only for the science subject but also other subjects in order to develop students' competencies.

\section{Conclusion}

Developing students' competencies to meet the learning outcomes set by the subject and the education level is a vital task at the moment. One of the fundamental approaches with the power to affect competency development is renovating teaching methods to maximize students' proactivity, autonomy, and creativity. This field study investigated the current teaching methods used for the science subject with an orientation toward competency development with the participation of 45 administrators, 354 teachers, and 1,880 students from 27 primary schools in 18/24 districts in Ho Chi Minh City. The findings reveal that the current teaching and learning of the science subject still revolve around conventional teaching methods in which the teachers give lectures while the students listen and memorize the lessons. The teachers hold the central role in the lessons. The most commonly used teaching methods were Q\&A and Instructions (which belong to the group of teaching methods using verbal and written language). The use of this teaching method group only helped students develop Feeling Competency and be able to recognize problems, leaving their Comprehension Competency and Doing Competency (putting knowledge into practice) underdeveloped. Therefore, students' competency failed to developed effectively and holistically. Students remain passive. Survey results show that during the science subject periods, students mostly "Answered questions raised by teacher or questions in textbooks" and "Listened to teacher's instruction and memorized the lesson conclusion". They have not been able to take initiative and only follow the lead of their teachers. They were not active and autonomous in their learning. Some students are slow in learning. Due to their shy nature, they are often left out and have to sit back from learning activities. When asked about learning activities, students expressed that they wanted to participate in games and to watch videos and pictures about the lessons. They would like to learn in nature, practice, experiment, role play, and discuss in groups. The field survey shows that the current teaching methods used to teach the science subject failed to develop students' competency. These findings provide objective and essential grounds for educators to design and organize learning activities, improving educational content and teaching methods in a way that would satisfy both students' needs for active learning and their competency development, meeting the requirements of the 2018 General Education Curriculum in VietNam. 


\section{References}

Dang, T.H., (2012). Năng lực và giáo dục theo tiếp cận năng lực. Journal of Education Management, $43,18-26$.

DeSeCo. (2002). Lifelong Learning and the Knowledge Economy: Key Competencies for the Knowledge Society. In: Proceedings of the DeSeCo Symposium. Stuttgart.

Do, H.T., (2015). Dạy học tích hợp phát triển năng lực học sinh. Hanoi University of Education Publishing House, Hanoi.

Eurydice (2006). Science teaching in schools in Europe: Policies and research. Eurydice European Unit, Brussels.

Gonczi, A., Hager, P., \& Athanasou, J., (1993). The development of competency-based assessment strategies for the professions. Australian Government Publishing Service, Australian Capital Territory, Canberra. http://hdl.voced.edu.au/10707/104071

Government of Ireland (1999). Science: Social, Environmental and Scientific Education. The Stationery Office, Dublin.

Hoang, H.B., (2015). Năng lực và đánh giá theo năng lực. Ho Chi Minh University of Education Journal of Science, 6 (71), 21-32.

Hoang, T.T., (2013). Phát triển chương trình đại học theo cách tiếp cận năng lực: Xu thế và nhu cầu. Journal of Development and Integration, 9(19), 80-87,

Jenkins, E.W., (2013). Children and the teaching and learning of science: A historical perspective. Proceedings of Children's Perspective on School, Teaching and Learning. Children's Perspective on School, Teaching and Learning, Catholic University of Eichstaett - Ingolstadt, Eichstaett.

Koutsoukos, M., Fragoulis, I., \& Valkanos, E., (2015). Connection of Environmental Education with Application of Experiential Teaching Methods: A Case Study from Greece. International Education Studies, 8(4), 23-28, DOI: https://doi.org/10.5539/ies.v8n4p23

Miller GE. (1990), The assessment of clinical skills/competence/ performance, Academic Medicine, 65: S63-67. https://doi.org/10.1097/00001888-199009000-00045

Ministry of Education (2015). 21st Century competencies. Queen's Printer.

Mulder, M., Weigel, T., \& Collins, K., (2007). The concept of competence in the development of vocational education and training in selected EU member states: a critical analysis. Journal of Vocational Education \& Training, 59(1), 67-88, https://doi.org/10.1080/13636820601145630

Nguyen, L., \& Nguyen, T. L. P. (Eds.). (2015). Phương pháp, kĩ thuật xây dựng chuẩn đánh giá năng lực đọc hiểu và năng lực giải quyết vấn đề: Chuyên khảo về khoa học giáo dục. Vietnam Education Publishing House, Hanoi

Nguyen, T.L.P. (Ed.). (2016). Chương trình tiếp cận năng lực và đánh giá năng lực người học. Vietnam Education Publishing House. Hanoi.

Nguyen, X.T. (2014). Giáo trình Tâm lí học đại cương. Hanoi University of Education Publishing House, Hanoi. 
OECD. (2002). Definition and Selection of Competencies: Theocretica and Conceptual Foundation: Strategy Paper, http://hdl.voced.edu.au/10707/156754

Ontario The Public Service (2016). 21st Century competencies: Foundation document for discussion. The Ontario Public Service, Winter 2016 Edition, Ontario.

Peacock, A. (2006). Science in primary schools: The multicultural dimension. Macmillan Education, United Kingdom

Quach, V.L. (2019). Phát triển năng lực sáng tạo cho học sinh trường trung học phổ thông chuyên thông qua dạy học dự án phần Hóa học hữu cơ. Journal of Educational Science, 15,

Québec-Ministere de L'Education (2004). Québec Education Program, Secondary School Education, Cycle One, Gouvernement du Québec.

Settlage, J., \& Southerland, S.A., (2007). Teaching science to every child: Using culture as a starting point, Taylor \& Francis, New York.

Vietnam's Ministry of Education and Training (2018a). Chương trình giáo dục phổ thông ban hành kèm theo Thông tư 32/2018/TT-BGDĐT.

Vietnam's Ministry of Education and Training, V. (2018b). Chương trình giáo dục phổ thông môn KHOA HỌC ban hành kèm theo Thông tư 32/2018/TT-BGDĐT.

Walma van der Molen, J.H., Aalderen-Smeets, S.I., \& Asma, L.J.F., (2010). Teaching science and technology at primary school level: Theoretical and practical considerations for primary school teachers' professional training. Proceedings of the IOSTE Symposium on Science and Technology Education. International Organization for Science and Technology Education, IOSTE.

Weinert, F.E., (2001). Vergleichende Leistungsmessung in Schulen-eine umstrittene Selbstverständlichkeit. In Leistungsmessungen in schulen (pp. 17-31). Weinheim und Basejl: Beltz Verlag

Does this article screened for similarity: YES

Funding: No funding was received for conducting this study.

Conflict of Interest: The authors have no conflicts of interest to declare that they are relevant to the content of this article.

\section{About the License}

(C) The author(s) 2021. The text of this article is open access and licensed under a Creative Commons Attribution 4.0 International License 